Vol. 15 (2006): 3-11.

\title{
Cadmium content of Finnish linseed and estimated consumer intake
}

\author{
Hanna-Riitta Kymäläinen and Anna-Maija Sjöberg \\ Department of Agrotechnology, PO Box 28, FI-00014 University of Helsinki, Finland, \\ e-mail: hanna-riitta.kymalainen@helsinki.fi
}

\begin{abstract}
The aim of this study was to screen the cadmium (Cd) contents of seed and seed crush of Finnish linseed and to evaluate the acceptable daily dose. The Cd content of Finnish linseed is of interest, since some properties of linseed as the content of fatty acids are different in northern growth locations compared with other growing areas. Seed samples $(N=85)$ were collected from the experimental farm of Helsinki University and from commercial fields in different locations in southern Finland and Ostrobothnia. In addition, 15 samples of linseed crush were examined. The cadmium contents of the linseed samples, determined with atomic absorption spectroscopy, varied between 0.27 and $1.3 \mathrm{mg} \mathrm{kg}^{-1}$ (dry weight) (mean $0.61 \mathrm{mg} \mathrm{kg}^{-1}$ ). The $\mathrm{Cd}$ contents of the crush samples were between 0.47 and $1.5 \mathrm{mg} \mathrm{kg}^{-1}$ (mean $0.85 \mathrm{mg} \mathrm{kg}^{-1}$ ). There were differences between the $\mathrm{Cd}$ contents of the three examined varieties and years at the experimental farm. Increase in nitrogen fertilization somewhat increased the $\mathrm{Cd}$ uptake of linseed. The permitted intake of linseed depends on body weight and on the $\mathrm{Cd}$ content of the product and is in most cases higher than the dietary recommendation (24-30 $\mathrm{g}$ daily dose of linseed).
\end{abstract}

Key words: linseed, Linum usitatissimum, cadmium, fertilizers, varieties, intake

\section{Introduction}

Linseed (Linum usitatissimum L.) has several positive effects on human health, e.g. favourable fatty acids, proteins and dietary fibre (Morris 2003). It has industrial interest as a functional food or as an ingredient of functional foods e.g. in the form of oil and crush (Oomah 2001). However, despite its numerous advantageous components promoting human health, linseed also contains some compounds not beneficial to health, including cadmium taken up from soil. In the form of the divalent ion $\mathrm{Cd}^{2+}$, cadmium is readily taken up by linseed even at low external concentrations (Chakravarty and Srivastava 1997). However, a wide variation 
Kymäläinen, H.-R. \& Sjöberg, A.-M. Cadmium content of linseed

of $\mathrm{Cd}$ content in the grain of linseed has been measured in various international studies (Table 1). Published results concerning the $\mathrm{Cd}$ content of Finnish linseed were not available. They, however, are of interest, since some properties of linseed as the content of fatty acids are different in northern growth locations compared with other growing areas (Kanta-Oksa 1992).

According to Codex Alimentarius Commission (2001), the maximum $\mathrm{Cd}$ content for cereals is 0.1 $\mathrm{mg} \mathrm{kg}^{-1}$ (dw, dry weight,), which corresponds to $0.11 \mathrm{mg} \mathrm{kg}^{-1}(\mathrm{dw})$ (moisture content of the seed between 5 and 13\%, wet basis). In Finland there is no official limit value of $\mathrm{Cd}$ for the food products (Tarpila et al. 2005). The German guide value for the $\mathrm{Cd}$ content of linseed is $0.3 \mathrm{mg} \mathrm{kg}^{-1}$ (fw, fresh weight) ( $\mathrm{Li}$ et al. 1997). The maximum permitted concentration for confectionery linseed traded on the international market is $0.25 \mathrm{mg} \mathrm{kg}^{-1}$ in Australia (Hocking and McLaughlin 2000). Similar values are used in various European countries (Liukkonen-Lilja and Penttilä 1992). For nonsmokers food is the main source of $\mathrm{Cd}$ (WHO 2000). However, in areas without heavy industrial pollution, cadmium exposure is mainly influenced by personal smoking habits (Heinzow et al. 1991). The Finnish estimated daily intake (EDI) is 10.8 $\mu \mathrm{g}$ per person according to Tahvonen (1995). In a study by Leblanc et al. (2000), the average French EDI for Cd was $17 \mu \mathrm{g}$ per person. An average dietary intake of $\mathrm{Cd}$ in some polluted Polish towns was $40 \mu \mathrm{g}$ per person (Skibniewska 2003), which was considered alarming.
The aim of this study was to screen the cadmium contents of seed and seed crush of Finnish linseed and to evaluate their acceptable daily intakes for humans. In addition, the differences between varieties and the effect of nitrogen fertilization on the cadmium contents were investigated.

\section{Material and methods}

A total of 24 seed samples were collected from the experimental farm of the University of Helsinki, located in Siuntio in southern Finland. As shown in Table 2, the samples were collected from different varieties and nitrogen fertilization levels with three replicates. In addition, 61 single seed samples were collected from commercial fields in different locations of southern Finland and Ostrobothnia. A total of 15 samples of linseed crush, produced from some of the commercial linseed samples were also examined. The crush samples were the residue after pressing oil from the seeds. In order to examine the possible relation of various parameters to the Cd levels, the following background data of the samples were collected: type and amount of fertilization, soil type, preceding crop and use of pesticides. Unfortunately this background data was not available for 13 commercial samples and six sowing seed samples, as is shown in Table 2.

The Cd contents of the samples were analysed by the City of Vantaa Food and Environmental

Table 1. Studies concerning cadmium content of linseed.

\begin{tabular}{lll}
\hline Examined linseed samples & Cd content, $\mathrm{mg} \mathrm{kg}^{-1}$ & Reference \\
\hline Yellow & mean 0.23 & Klein \& Weigert 1987 \\
Brown & mean 0.38 & Klein \& Weigert 1987 \\
118 seed samples and 16 genotypes & $0.10-1.70(\mathrm{dw})$ & Marquard et al. 1990 \\
14 commercial varieties & $0.02-0.10(\mathrm{fw})$ & Li et al. 1997 \\
60 plant introduction lines & $0.14-1.37(\mathrm{fw})$ & Li et al. 1997 \\
Cultivars grown under experimental & 0.23 and $0.55(\mathrm{dw})$, no differences between & Hocking \& McLaughlin 2000 \\
conditions & the brown and yellow seeded varieties & \\
\hline
\end{tabular}

$\mathrm{dw}=$ dry weight, $\mathrm{fw}=$ fresh weight 
Vol. 15 (2006): 3-11.

Table 2. Linseed samples, areal origin and year of harvesting.

\begin{tabular}{|c|c|c|c|c|}
\hline \multirow[t]{2}{*}{ Areal origin of the samples } & \multicolumn{4}{|c|}{ Year of harvesting } \\
\hline & 2002 & 2003 & 2002 or $2003^{*}$ & 2004 \\
\hline $\begin{array}{l}\text { Experimental farm of Helsinki } \\
\text { University, Siuntio (southern }\end{array}$ & 3 seed samples: & 9 seed samples: & - & 12 seed samples: \\
\hline Finland) & $\begin{array}{l}3 \text { replicates of } \\
\text { var. Laser }\end{array}$ & $\begin{array}{l}3 \text { replicates of } \\
\text { varieties Helmi, } \\
\text { Laser and the Bor } \\
\text { breeding line }\end{array}$ & & $\begin{array}{l}9 \text { replicates of var. Laser: } \\
3 \text { replicates for each of } \\
\text { the } \mathrm{N} \text { fertilisation levels } \\
\text { of } 40,60 \text { and } 80 \mathrm{~kg} \mathrm{ha}^{-1} \text {. } \\
3 \text { replicates of var. } \\
\text { Helmi: } \mathrm{N} \text { fertilisation } \\
\text { level of } 60 \mathrm{~kg} \mathrm{ha}^{-1} \text {. }\end{array}$ \\
\hline $\begin{array}{l}\text { Southern Finland, commercial } \\
\text { farms }\end{array}$ & $\begin{array}{l}3 \text { seed samples } \\
1 \text { crush sample }\end{array}$ & 25 seed samples & 8 seed samples & - \\
\hline & & 9 crush samples & 5 crush samples & \\
\hline Ostrobothnia, commercial farms & 8 seed samples & 17 seed samples & - & - \\
\hline Unknown areal origin of sowing & - & - & 6 seed samples: & - \\
\hline & & & $\begin{array}{l}3 \text { replicates of sowing } \\
\text { seed of Helmi and the } \\
\text { Bor breeding line }\end{array}$ & \\
\hline
\end{tabular}

- No samples

* exact year not available

Laboratory, an accredited laboratory. The method was the standard method NMKL 161, based on atomic absorption spectroscopy. Samples were homogenized and combusted in a wet combustion apparatus (Milestone Ethos Plus) with nitric acid and hydrogen peroxide. Also zero tests without sample were carried out for each combustion. The samples were analyzed with atomic absorption spectroscopy in a graphite oven (Perkin Elmer Simaa 6100) with background correction (Zeeman). A reference material BCR No 279 (Sea Lettuce) was used. The uncertainty of the measurements was $\pm 18 \%$ ( $95 \%$ confidence interval) in the range between $0.3 \mathrm{mg} \mathrm{kg}^{-1}$ and $1.5 \mathrm{mg} \mathrm{kg}^{-1}$.

Variance analysis (One-way ANOVA, Tukeys's post hoc test) of the SPSS statistical tool was used to examine the possible differences in cadmium content of the samples between the growing areas southern Finland and Ostrobothnia. Bivariate correlation analysis of the SPSS tool was used to examine the correlation between the $\mathrm{Cd}$ content and nitrogen fertilization level of the seed samples.

\section{Results}

\section{Cadmium content of linseed}

The Cd content of the linseed samples varied between 0.27 and $1.3 \mathrm{mg} \mathrm{kg}^{-1}(\mathrm{dw})$, with a mean value of $0.62 \mathrm{mg} \mathrm{kg}^{-1}$. The Cd contents of the crush samples were between 0.47 and $1.5 \mathrm{mg} \mathrm{kg}^{-1}(\mathrm{dw})$, with a mean of $0.85 \mathrm{mg} \mathrm{kg}^{-1}$. As shown in Fig. 1, the $\mathrm{Cd}$ contents of seeds grown in the Ostrobothnia area were somewhat lower (mean $0.48 \mathrm{mg} \mathrm{kg}^{-1}$ ) than those of seeds grown in southern Finland (mean $0.67 \mathrm{mg} \mathrm{kg}^{-1}$ ). Despite the internal variation within the two areas, seen as a variation range of $0.27-1.3 \mathrm{mg} \mathrm{kg}^{-1}$ for the southern samples and $0.27-0.96 \mathrm{mg} \mathrm{kg}^{-1}$ for the northern samples, the difference between the two major areas was statistically significant $(\mathrm{P}<0.005)$. However, because the samples from Siuntio had a higher Cd content than all the other southern samples (Fig. 1), the areal differences were analyzed further. The variance 
Kymäläinen, H.-R. \& Sjöberg, A.-M. Cadmium content of linseed

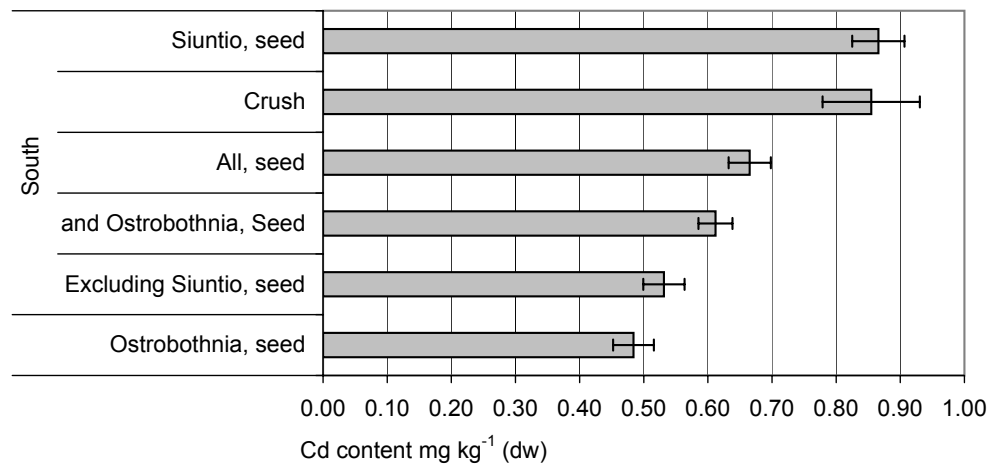

Fig. 1. Cadmium contents of linseed samples from different growing areas ( $\mathrm{dw}=$ dry weight $)$. Columns are means and bars in columns standard errors of the means of the replicates. Number of replicates is presented in Table 2.

analysis showed statistically significant differences between Siuntio and Ostrobothnia but also between Siuntio and the other southern areas ( $\mathrm{P}$ value in the Tukey's test $<0.001$ in both cases). When Siuntio was excluded from the southern samples, there was no statistically significant difference between Ostrobothnia and southern Finland $(\mathrm{P}>$ $0.05)$.

The cadmium content of the crush samples, produced from other southern samples than those from Siuntio, was at the same level as that of the seed samples of Siuntio (Fig. 1). However, as shown in Fig. 2, the Cd contents of the all crush samples were higher than those of the corresponding seed samples from the commercial farms. The increase in the $\mathrm{Cd}$ content in the seed residue after pressing of oil was $56 \%$ on average, varying from $12 \%$ (Sample 9) to $138 \%$ (Sample 15).

Figure 3 provides an indication of the differences between the $\mathrm{Cd}$ contents of the varieties and years. In the year 2003, the Bor line had the highest and 'Laser' the lowest Cd content. However, in 2004 there was no difference between 'Laser' and 'Helmi'. As presented in Fig. 3, at the experimental farm of Siuntio the increase in nitrogen fertilization level somewhat increased the $\mathrm{Cd}$ intake of

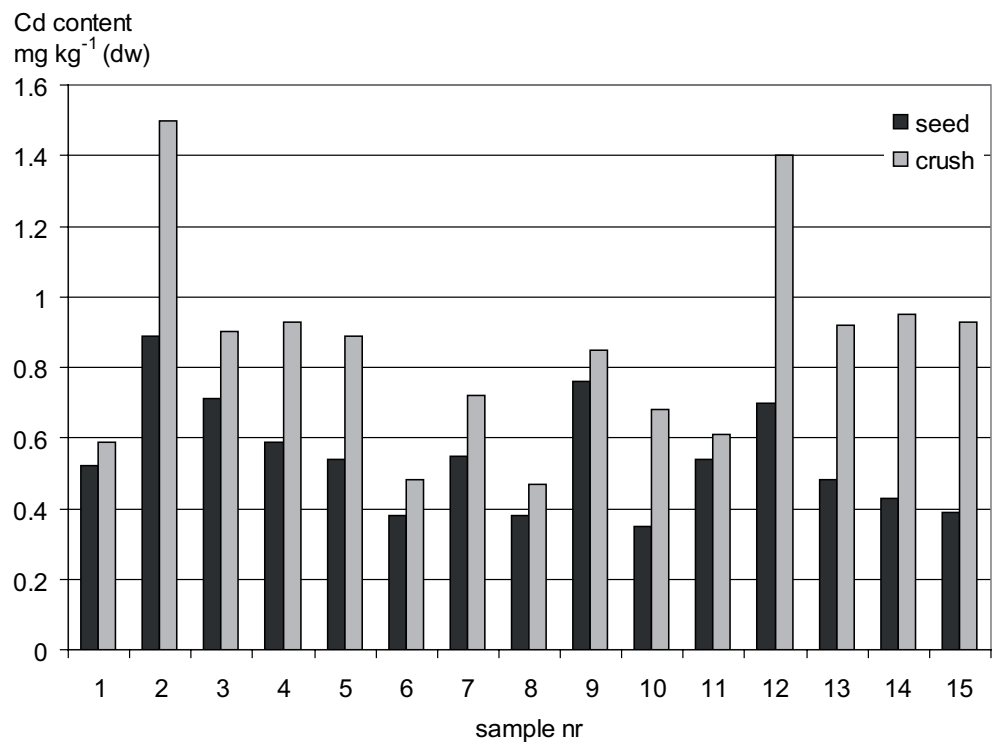

Fig. 2. Comparison of the cadmium contents of the grouts and of the corresponding seed samples from commercial farms. Results are single measurements of the samples. 
Vol. 15 (2006): 3-11.

'Laser' in 2004. Only a weak general correlation between $\mathrm{Cd}$ content and the nitrogen fertilization level was found when all seed samples with a known nitrogen fertilization background data $(\mathrm{N}=$ 72) were analyzed (Pearson's correlation coefficient $0.41, \mathrm{P}<0.01$ ). The types of fertilization, soil types, preceding crops and use of pesticides were extremely variable and could not be used for explaining the $\mathrm{Cd}$ contents of the samples. Use of organic fertilization (manure or similar) was not associated with high $\mathrm{Cd}$ values, but the number of samples was too low to allow definite conclusions.

\section{Estimated intake}

In a clinical study by Tarpila et al. (2004), the blood cadmium of patients remained unchanged after six months of linseed treatment, and ground flaxseed was considered safe at a daily dose of up to $24 \mathrm{~g}$. According to Morris (2003), a daily dose of $30 \mathrm{~g}$ of linseed is optimal for utilization of functional components as fatty acids. These recommended values for daily dose of linseed were used as references for intake estimations. By comparing the Cd values from the present study (seed 0.27$1.3 \mathrm{mg} \mathrm{kg}^{-1}$, crush $0.47-1.5 \mathrm{mg} \mathrm{kg}^{-1}$ ) with the $24 \mathrm{~g}$ reference values, the estimated daily intake of $\mathrm{Cd}$ is 6.5-31 $\mu \mathrm{g} \mathrm{Cd}$ (seed) and 11-36 $\mu \mathrm{g} \mathrm{Cd}$ (crush). These values are $9.3-44 \%$ (seed) and $14-51 \%$ (crush) of the provisional tolerable daily intake (PTDI) value $\left(70 \mu \mathrm{g} \mathrm{d}^{-1}\right)$ presented by WHO and FAO (1993). By comparing the Cd values from the present study with the $30 \mathrm{~g}$ reference values, the EDI of $\mathrm{Cd}$ is $8.1-39 \mu \mathrm{g}$ (seed) and $14-45 \mu \mathrm{g}$ (crush). These values are $11-55 \%$ (seed) and 20$63 \%$ (crush) of the $70 \mu \mathrm{g} \mathrm{d}^{-1}$ PTDI value.

If all the $\mathrm{Cd}$ consumed by an individual originated from the linseed studied here, the maximum daily dose related to the PTDI value of WHO would be 55-263 g linseed seed or 47-151 g linseed crush for a person with a $70 \mathrm{~kg}$ body weight, depending on the $\mathrm{Cd}$ content of linseed. However, because linseed and linseed products are consumed only in small amounts, the Cd intake should be evaluated accordingly. Furthermore, the body weights of different people vary considerably, leading to a need for personal recommendations of intakes e.g. in health advisory institutions. Therefore the body weights $50 \mathrm{~kg}, 70 \mathrm{~kg}$ and $90 \mathrm{~kg}$ are used in the following. The Finnish maximum EDI
Fig. 3. Cadmium contents of varieties Laser, Helmi and the line Bor grown in Siuntio, southern Finland. Columns are means and bars in columns the variation range (min-max) of the three replicates. The $\mathrm{N}$ fertilization levels of $40 \mathrm{~kg} \mathrm{ha}^{-1}, 60 \mathrm{~kg} \mathrm{ha}^{-1}$ and $80 \mathrm{~kg}$ $\mathrm{ha}^{-1}$ are given in parentheses.

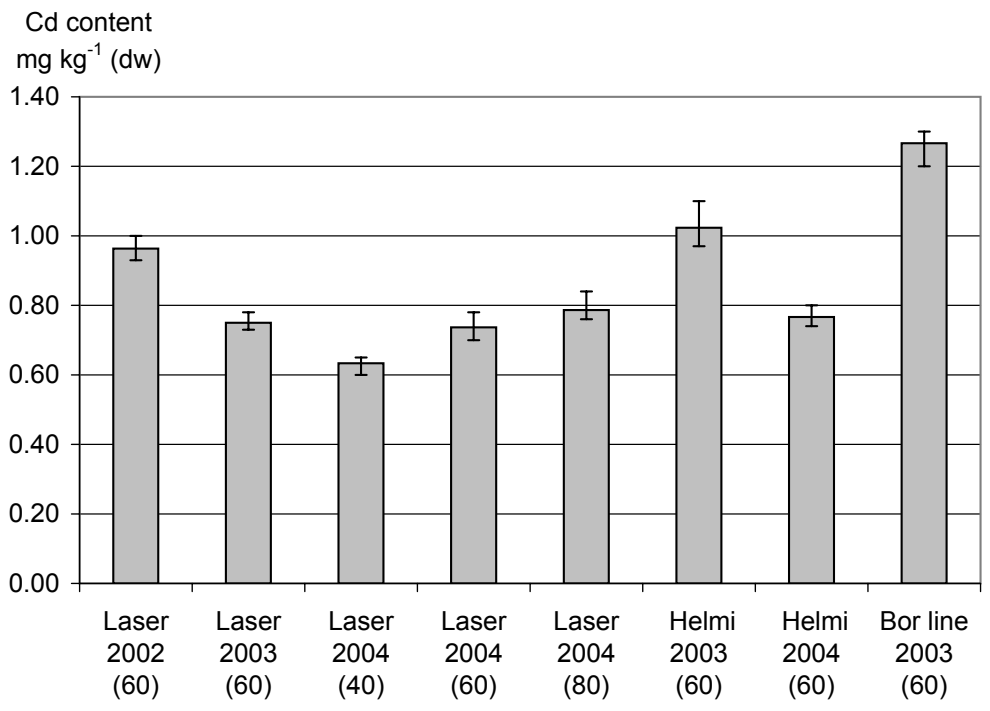


of $11 \mu \mathrm{g}$ in food is equivalent to $15 \%$ of PTDI (Tahvonen 1995), and the French EDI of $17 \mu \mathrm{g}$ (Leblanc et al. 2000) corresponds to 24\% of PTDI (70 $\mu \mathrm{g}, \mathrm{WHO}$ ). Similarly, a high EDI of $40 \mu \mathrm{g}$ (Skibniewska 2003) corresponds to 57\% of PTDI. If we injest $\mathrm{Cd}$ from linseed in addition to this basal EDI $(11-40 \mu \mathrm{g})$, the possible additional daily intake of Cd would be 30-60 $\mu \mathrm{g}$. As can be seen in Figure 4, the additional permitted intake of linseed strongly depends on body weight. In most cases the permitted intake is even higher than that associated with the dietary recommendation of 24-30 $\mathrm{g}$ linseed, but in the case of a relatively low body weight $(50 \mathrm{~kg})$ the limit is rather close if linseed with a high $\mathrm{Cd}$ content is used.
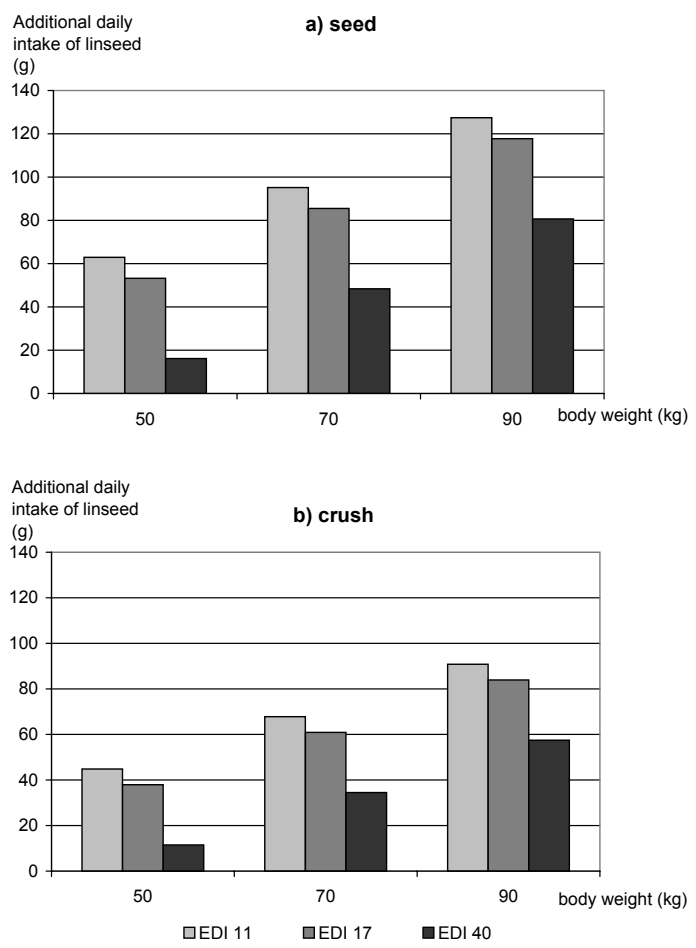

Fig. 4. Estimated average intake of seed and crush of linseed for persons with different body masses, when linseed is considered as an additional source of cadmium. The estimates are calculated from means of the cadmium contents of (a) seed and (b) crush for estimated daily intake values of $11 \mu \mathrm{g}$ (Finnish), $17 \mu \mathrm{g}$ (French value) and $40 \mu \mathrm{g}$ (polluted Polish area).

\section{Discussion}

The Cd contents of most seed samples were between $0.30 \mathrm{mg} \mathrm{kg}^{-1}$ and $0.90 \mathrm{mg} \mathrm{kg}^{-1}(\mathrm{dw})$. A few samples had a Cd content below $0.30 \mathrm{mg} \mathrm{kg}^{-1}$, which is the German limit value for linseed. All values were above the Codex Alimentarius Commission limit of $0.1 \mathrm{mg} \mathrm{kg}^{-1}$, which however is set for cereals that are consumed in large amounts compared with linseed.

Cadmium accumulation in the seed of linseed may be influenced by a number of factors, e.g. fertilizer application ( $\mathrm{Cd}$ content of the fertilizer), use of sewage sludge, soil type and $\mathrm{pH}$, and agronomic practices (Guo et al. 1995, Hocking and McLaughlin 2000). In a study by Jiao et al. (2004), zinc addition at $20 \mathrm{mg} \mathrm{Zn} \mathrm{kg}^{-1}$ soil with phosphorus decreased seed $\mathrm{Cd}$ concentration by $42 \%$. Low soil $\mathrm{pH}$ can increase soil Cd solubility (Eriksson et al. 1996). In a study of Matthäus and Zubr (2000), the combined effect of climatic and soil conditions affected the accumulation of heavy metals in camelina seed. In a study of oats by Eurola et al. (2003), the samples with highest $\mathrm{Cd}$ values had grown in dry, warm conditions leading to low biomass and a relatively high concentration of $\mathrm{Cd}$ in the plant tissues. In the present study, the warm growing season of the year 2003 led to a higher Cd content in the variety Helmi than the wet growing season of 2004 at the experimental farm of Siuntio, whereas there was no corresponding difference in the variety Laser.

In the present study, the linseed grown in the northern province of Ostrobothnia had a somewhat lower $\mathrm{Cd}$ content on average than linseed grown in southern Finland. However, the Cd contents of the samples from Siuntio were significantly higher than those of the samples from the other southern locations. Reason for that should be investigated. In the study by Eurola et al. (2003), the lowest Cd values of oats were measured in the northern trial locations in Finland. The Cd content of Finnish soils is higher in southern than in northern parts of the country (Sippola and Mäkelä-Kurtto 1986, Louekari et al. 2000), which affects the Cd content of cereals accordingly (Liukkonen-Lilja and Pent- 
Vol. 15 (2006): 3-11.

tilä 1992). In the present study this result was not confirmed for all southern samples. Flax used for food applications should not be grown in polluted areas (Marquard et al. 1990, Grant et al. 2000, Angelova et al. 2003). In the study by Angelova et al. (2003), cadmium contents as high as $2.3 \mathrm{mg} \mathrm{kg}^{-1}$ were measured in flaxseed at a distance of $0.5 \mathrm{~km}$ from an industrially polluted area, whereas $15 \mathrm{~km}$ from the polluted area the flax seed accumulated only $0.52 \mathrm{mg} \mathrm{kg}^{-1}$. Industrial emission sources of Cd include e.g. the mining, steel and fertilizer industries and energy production (Liukkonen-Lilja and Penttilä 1992). This should direct the selection of growing areas for linseed, although in practice a consumer will probably not consistently eat linseed with the highest contaminant level.

As was seen in the present study and in other studies (Marquard et al. 1990, Li et al. 1997), cadmium uptake of linseed from the soil is clearly cultivar dependent. The results indicate that it is possible to select for low Cd uptake genotypes in future breeding programs. Cadmium interacts with e.g. zinc ions, and Chakravarty and Srivastava (1997) showed that by adding $\mathrm{Zn}^{2+}$ to a growth medium at a non-toxic level it is possible to regenerate linseed plants tolerant to $\mathrm{Cd}^{2+}$. Hocking and McLaughlin (2000) also suggested utilization of genotypic differences in reducing $\mathrm{Cd}$ concentrations in linseed, because many of the soil and site factors are difficult for producers to control. However, more investigations are needed for developing varieties with this feature.

The Cd content of the seed residue after separation of oil was higher than that of the whole seed. In a study by Hocking and McLaughlin (2000), the cadmium contents of the de-seeded capsules and the seeds of linseed varied only slightly compared to other oilseed plants, and ineffective barriers discriminating against the transport of $\mathrm{Cd}$ to seed were proposed. In a study of Jiao et al. (2004), ineffective barriers discriminating against the transport of $\mathrm{Cd}$ from the root to the shoot, and restriction of Cd translocation to the seed via the phloem were found. Li et al. (1997) suggested that there is no relationship between the oil content of a crop and its patterns of $\mathrm{Cd}$ accumulation. Cadmium did not penetrate markedly into the pressed oil of camelina (Matthäus and Zubr 2000). In accordance with this result, Lei et al. (2003) showed that the major Cd-binding fraction in the seed of linseed is associated with one part of the proteins, and proposed that it could be possible to isolate the major storage protein of flaxseed with a low $\mathrm{Cd}$ content. However, an industrially feasible separation method would be necessary (Oomah and Mazza 1993).

Several limit values are used for evaluation of the maximum human intake of harmful chemical substances. The acceptable daily intake (ADI) value relates to lifelong use. Short-term intakes can be accepted at exposure levels exceeding the ADI. Some contaminants have tolerable daily intake and provisional tolerable weekly intake (PTWI) values (Nordberg 1999). In the cited study, exposures to $200 \mu \mathrm{g}$ daily intakes for months or even years were estimated to be tolerated without obvious gastrointestinal symptoms or other indications. On the other hand, in a study of Meberg et al. (1979), the daily amount of $\mathrm{Cd}$ which can cause accumulation in the body was considered to be 200-300 $\mu$ g. According to WHO and FAO (1993), the present PTWI for $\mathrm{Cd}$ is $500 \mu \mathrm{g}$, often expressed as a provisional tolerable daily intake of $70 \mu \mathrm{g}$ or $1 \mu \mathrm{g} \mathrm{kg}^{-1}$ body weight.

\section{Conclusion}

Cadmium content of the Finnish linseed was in general similar than what has been measured in previous international studies, although there was marked variation both in the present and previous studies. Samples taken from Siuntio were significantly higher than those of the samples from the other southern locations, and the reason for that should be studied. In the case of a normal Finnish diet with a relatively low EDI $(11 \mu \mathrm{g})$, the nutritionally recommended daily dose of linseed (24$30 \mathrm{~g}$ ) can safely be consumed if the present PTDI value set by WHO is applied. If the normal diet contains a large amount of $\mathrm{Cd}$ or the body weight of the person is low, the recommended daily doses 
Kymäläinen, H.-R. \& Sjöberg, A.-M. Cadmium content of linseed

should be lowered at least when using linseed with a high $\mathrm{Cd}$ content. Growing areas with a low $\mathrm{Cd}$ content should be favoured in the cultivation of linseed. There was some evidence in the present study of an increase of $\mathrm{Cd}$ content of linseed due to increased nitrogen fertilization. Furthermore, the differences between linseed varieties should be considered when selecting varieties for breeding and cultivation.

Acknowledgements. We are grateful to the Agro Fibre Network project in the EMOTR/ALMA program for financial support. We warmly thank Aija Kortesmaa, Hanna Kinnunen, Ari Klemola, Minna Nykter and Eero Lamminen for expertise, assistance and fruitful discussions during the study. Finnish linseed companies Elixi Oil Oy, Oy Linseed Protein Finland Ltd, Neomed Oy and Sini-Pellava Oy are acknowledged for cooperation and for providing the samples.

\section{References}

Angelova, V., Ivanova, R., Delibaltova, V. \& Ivanov, K. 2003. Bio-accumulation and distribution of heavy metals in fibre crops (flax, cotton and hemp). Industrial Crops and Products 19: 197-205.

Chakravarty, B. \& Srivastava, S. 1997. Effect of cadmium and zinc interaction on metal uptake and regeneration of tolerant plants in linseed. Agriculture, Ecosystems and Environment 61: 45-50.

Codex Alimentarius Commission 2001. CAC/GL 39-2001, Codex maximum level for cadmium in cereals, pulses and legumes. WHO and FAO. 1 p.

Eriksson, J.E., Öborn, I., Jansson, G. \& Andersson, A. 1996. Factors influencing Cd-content in crops. Results from Swedish field investigations. Swedish Journal of Agricultural Research 26: 125-133.

Eurola, M., Hietaniemi, V., Kontturi, M., Tuuri, H., Pihlava, V.-M., Saastamoinen, M., Rantanen, P., Kangas, A. \& Niskanen, M. 2003. Cadmium contents of Oats (Avena sativa L.) in official variety, organic cultivation, and nitrogen fertilization trials during 1997-1999. Journal of Agricultural and Foods Chemistry 51: 2608-2614.

Grant, C.A., Dribnenki, J.C.P. \& Bailey, L.D. 2000. Cadmium and zinc concentrations and ratios in seed and tissue of solin (cv. Linola ${ }^{\mathrm{TM}}$ 947) and flax (cvs McGregor and Vimy) as affected by nitrogen and phosphorus fertiliser and Provide (Penicillium bilaji). Journal of the Science of Food and Agriculture 80: 1735-1743.

Guo, Y., Schultz, R. \& Marschner, H. 1995. Genotypic differences in uptake and distribution of cadmium and nickel in plants. Angewandte Botanik 69: 42-48.

Heinzow, B., Jessen, H., Mohr, S. \& Riemer, D. 1991. Heavy metals in the general population: trend evaluation and interrelation with trace elements. In: Aitio, A. et al. (eds.). Trace elements in health and disease. Great Britain: The Royal Society of Chemistry. p. 75.

Hocking, P.J. \& McLaughlin, M.J. 2000. Genotypic variation in cadmium accumulation by seed of linseed, and comparison with seeds of some other crop species. Australian Journal of Agricultural Research 51: 427-433.

Jiao, Y., Grant, C.A. \& Bailey, L.D. 2004. Effect of phosphorus and zinc fertilizer on cadmium uptake and distribution in flax and durum wheat. Journal of the Science of Food and Agriculture 84: 777-785.

Kanta-Oksa, R. 1992. Uusi pellavakirja. 2. ed. Sonkajärvi: Ylä-Savon Instituutti. 128 p.

Klein, H. \& Weigert, P. 1987. Schwermetalle in Leinsamen. Bundesgesundheitsblatt 30: 391-395.

Leblanc, J.-C., Malmauret, L., Guérin, T., Bordet, F., Boursier, B. \& Verger, P. 2000. Estimation of the dietary intake of pesticide residues, lead, cadmium, arsenic and radionuclides in France. Food Additives and Contaminants 17: 925-932.

Lei, B., Li-Chan, E.C.Y., Oomah, B.D. \& Mazza, G. 2003. Distribution of cadmium-binding components in Flax (Linum usitatissimum L.) seed. Journal of Agricultural and Foods Chemistry 51: 814-821.

Li, Y.-M., Chaney, R.L., Schneiter, A.A., Miller, J.F., Elias, E.M. \& Hammond, J.J. 1997. Screening for low grain cadmium phenotypes in sunflower, durum wheat and flax. Euphytica 94: 23-30.

Liukkonen-Lilja, H. \& Penttilä, P.-L. 1992. Cadmium in cereals and grain products. National Food Administration, Research Notes 6/1992. 17 p.

Louekari, K., Mäkelä-Kurtto, R., Pasanen, J., Virtanen, V., Sippola, J. \& Malm, J. 2000. Cadmium in fertilizers. Risk to human health and the environment. Ministry of Agriculture and Forestry, Publications 4/2000.119 p.

Marquard, R., Boehm, H. \& Friedt, W. 1990. Untersuchungen über Cadmiumgehalte in Leinsaat (Linum usitatissimum L.). Fat Science and Technology 92: 468-472.

Matthäus, B. \& Zubr, J. 2000. Variability of specific components in Camelina sativa oilseed cakes. Industrial Crops and Products 12: 9-18.

Meberg, A., Sande, H., Foss, O.P. \& Stenwig, J.T. 1979. Smoking during pregnancy - effects on the fetus and on thiosyanate levels in mother and baby. Acta Paediatrica Scandinavica 68: 547-552.

Morris, D.H. 2003. Flax, a health and nutrition primer. Winnipeg: Flax Council of Canada. $112 \mathrm{p}$.

NMKL 161. Metals. Determination by atomic absorption spectrophotometry after wet digestion in a microwave oven. Norway: National Veterinary Institute, 1998.

Nordberg, G. 1999. Excursions of intake above ADI: case study on cadmium. Regulatory Toxicology and Pharmacology 30: S57-S62.

Oomah, B.D. 2001. Flaxseed as a functional food source. Journal of Science of Food and Agriculture 81: 889894.

Oomah, B.D. \& Mazza, G. 1993. Flaxseed proteins - a review. Food Chemistry 48: 109-114.

Sippola, J. \& Mäkelä-Kurtto, R. 1986. Cadmium in cultivated Finnish soils. Annales Agriculturae Fenniae 25: 255263. 
Vol. 15 (2006): 3-11.

Skibniewska, K.A. 2003. Diet monitoring for assessment of human exposure to environmental pollutants. Environment International 28: 703-709.

Tahvonen, R. 1995. Contents of lead and cadmium in foods in Finland. University of Turku, Department of Biochemistry and Food Chemistry, Turku, Finland. Academic dissertation. $115 \mathrm{p}$.

Tarpila, S., Tarpila, A., Gröhn, P., Silvennoinen, T. \& Lindberg, L. 2004. Efficacy of ground flaxseed on constipation in patients with irritable bowel syndrome. Current Topics in Nutraceutical Research 2: 119-125.
Tarpila, A., Wennberg, T. \& Tarpila, S. 2005. Flaxseed as a functional food. Current Topics in Nutraceutical Research 3: 167-188.

WHO 2000. Air quality guidelines. 2nd ed. Copenhagen, Denmark: WHO Regional Office for Europe. 273 p.

WHO and FAO 1993. Cadmium. In: Evaluation of certain food additives and contaminants. The 41st Meeting of the Joint FAO/WHO Expert committee on Food Additives. WHO Technical Reports Series 837. p. 28-30.

\title{
SELOSTUS
}

\section{Suomalaisen öljypellavan kadmiumpitoisuus ja arvioitu saanti kuluttajille}

\author{
Hanna-Riitta Kymäläinen ja Anna-Maija Sjöberg \\ Helsingin yliopisto
}

Tutkimuksen tavoitteena oli selvittää suomalaisen öljypellavan siemenen ja rouheen kadmiumpitoisuus ja arvioida hyväksyttävää päiväsaantia. Siemennäytteet $(\mathrm{N}=$ 85) kerättiin Helsingin yliopiston koetilalta sekä kaupallisilta viljelmiltä Etelä-Suomesta ja Pohjanmaalta. Lisäksi tutkittiin 15 pellavarouhenäytettä. Öljypellavanäytteiden kadmiumpitoisuus määritettiin atomiabsorptiospektrometrisesti, ja se vaihteli 0,27 ja $1,3 \mathrm{mg} / \mathrm{kg}$ välillä (keskiarvo $0,61 \mathrm{mg} / \mathrm{kg}$ ); pitoisuudet on ilmoitettu kuivamassaa kohti. Rouhenäytteiden Cd-pitoisuudet olivat $0,47-1,5 \mathrm{mg} / \mathrm{kg}$ (keskiarvo $0,85 \mathrm{mg} / \mathrm{kg}$ ). Koetilalla viljeltyjen kolmen öljypellavalajikkeen kadmiumpitoisuus vaihteli lajikkeittain ja myös eri vuosina. Typpilannoituksen lisäys lisäsi pellavan maasta ottamaa Cd-määrää jonkin verran. Sallittu kadmiumin saanti riippuu kehon painosta ja tuotteen Cd-pitoisuudesta, ja se on useimmissa tapauksissa suurempi kuin suositeltu syöntimäärä (24-30 g päivittäinen annos öljypellavaa). 